\title{
ENHANCING THE PROJECT DELIVERY QUALITY; LEAN CONSTRUCTION CONCEPTS OF DESIGN-BUILD \& DESIGN-BID-BUILD METHODS
}

\author{
Ihab M. Katar \\ Construction Management Program, Department of Engineering Management, \\ College of Eng., Prince Sultan University, Riyadh, Saudi Arabia
}

\begin{abstract}
Project delivery quality (PDQ) is a potential target of the construction team, which is working on enhancing this quality thru project stages: design and construction. A very important side of this work is study and research to investigate the critical factors affecting PDQ. Some former studies uncovered that the delivery methods: Design-Build $(D B)$ and Design-Bid-Build (DBB) notably affecting PDQ. A study appraised the mentioned methods among several features, such as: time, communication, drawings ...etc. This paper assumes that there are other critical features to be studied as it's believed to complete the appraisal among $D B$ and $D B B$. The aim of this paper is to get sound results for deciding which of them will contribute in enhancing $P D Q$. The paper will run unstructured conversations with design and construction players: owners, consultants (design/supervision), and contractors. They were requested to provide their feedbacks regarding (6) chosen features among $D B \& D B B$. Also, they were asked to justify their scores adding more details. Collected data was organized, tabulated, and analyzed, then discussed, and concluded.
\end{abstract}

Keywords: Lean construction - Project delivery quality (PDQ) - construction project Design-Build (DB) - Design-Bid-Build (DBB).

Cite this Article: Ihab M. Katar, Enhancing the Project Delivery Quality; Lean Construction Concepts of Design-Build \& Design-Bid-Build Methods, International Journal of Management, 10 (6), 2019, pp. 324-337.

http://iaeme.com/Home/issue/IJM?Volume $=10 \&$ Issue $=6$

\section{INTRODUCTION}

Several methods interpreted the contracts' types were controlling and leading the whole project among its different stages. Most well-known contracts/delivery methods are being used in those projects are the DB and DBB. The amount of results' differences among both of them worth having deeper studies to discover and recommend the best to use or, at least, the circumstances to use any of them. 
Being DB in nature, the involvement of the consultants was easier, as they were contracted to the main contractor (the direct participant in the project), and the contractor also has a closer and earlier involvement of the main contractor in the design process with more consideration of build-ability issues [1].

$\mathrm{DB}$ is not a new method of project delivery; its roots go back to antiquity. $\mathrm{P}$ Thomas mentioned that the pyramids were built though DB, as well as Saint Paul's Cathedral in London, but it fell into disuse in the United States about the time of the Civil War, and gave way to the "new" design-bid-build process through the latter years of the 20th century [2]. Also, he said that the DB delivery of buildings makes it less expensive and more certain that owners will get high performance and sustainability from their new buildings and renovation projects.

Although the importance of DB operational differences is widely accepted, there is as yet little agreement of their classification. Different rules and terminologies are used and some of the classifications are contradictory [3]. For example, Janssens D.E.L (1991) and Akintoye A. (1994) consider Design and Manage to be a DB variant [4, 5], while Masterman, J.W.E. (1992), in contrast, refer to Design and Manage as a management-oriented procurement system [6]. Quatman G.W. (2001) and Gransberg D.D et al. (2006) include Bridging as a DB variant [7, 8]. In Beard et al. (2001) classification framework however, Bridging is not regarded as DB, because it is more akin to traditional Design Bid Build and the client/owner is again in the position of warranting the completeness of the design to the bridging contractor [9].

Also, it's worth mentioning that The Direct DB process is qualifications-based, which involves the selection of a contractor through negotiation, and the selection of the team is primarily based on qualitative criteria such as past performance, design-builder reputation, and financial stability $[9,10]$. The DB method provides client/owners with an opportunity for alternative methods of selection. With different contractor selection methods, the designbuilder can be selected based solely on qualifications and price, or a combination of the two, which are reflected in Direct DB and Competitive DB approaches [3].

On the other hand, DBB the traditional method of design and construction, does not work as well as DB in the new sustainable environment [2].

This is considered as a continuation of a previous research, which evaluated the use of both methods in construction projects through a sum of (5) features: time-drawings-calendarcommunication-changes [11]. In this paper, the study assumes that there are still important (6) features to appraise among the two methods, as listed in the research approach later.

\subsection{Lean Construction}

For future work, it's proposed to develop a prospective model incorporating Lean, Green, and Six Sigma tools to prevent waste by diagnosing in advance the planned processes likely to produce waste [12]. Regarding the communication, Lean enabled more contact between senior managers and young line managers whom can employ the language of lean as a new vehicle for career progression [13].

On the other hand, by applying the Lean Subcontracting Procurement Process (LSPP), contractors gain opportunities to apply advanced technological tools, improve innovation in construction projects, and receive long-term benefits [14]. They also mentioned that the observed results from applying this LSPP to the real projects are largely positive and consistent. Generally, and related to collaborative work, partnerships can be expected to facilitate implementation of lean principles better than other traditional procurement methods [15].

The main barriers to the implementation of lean construction are (three), and identified as the lack of (1) understanding of the concept, (2) integration of design and construction and (3) efficient communication between different participants involved [16]. 
In construction field, the development of integrated management of work flow practices seem to be a better application of lean thinking to control the variability in construction [17]. Also, Lean construction as a form of organization cannot be understood in isolation from longterm structural changes at the sector level [18].

However, practitioners are expected to utilize lean construction principles in practice more frequently and realize full potential of the lean construction philosophy [19]. It was noticed that the positive effects of lean principles and methods on project management become more obvious as project complexity and the corresponding level of risk rise [20]. At last, and with reference to the economic dimension, the potential human cost of lean production should certainly be given equal status alongside its potential for reducing cost [21].

\subsection{Problem Statement}

Many factors are affecting construction projects among their life cycles, causing, sometimes, problematic issues that are reflected on the final outcomes, especially what is linked to PDQ. One of those important factors is the project delivery methods, and the most central two of them are $\mathrm{DB}$ and DBB.

The problem is that there is no clear right or wrong regarding the use of any of them in spite of many studies tried earlier to figure out the winner of the competition. Some studies nominated DB to be more suitable in most projects, whereas some others went to DBB. This issue lead project owner to get indecisive while preparing for a new project. Here, the paper adds a new trial for choosing the more fitting option to apply thru finding a more clearly way to distinguish among the delivery methods.

\subsection{Research Objectives}

This paper aims to reach the right decision while choosing any of the two project delivery methods: DB and DBB. This is to contribute the success in achieving the final outcomes related to PDQ, including cost and time. To reach this target, some objectives have been defined as follows:

- Assess key features as the subject of appraisal among the two delivery methods.

- Apply the concepts of Lean Construction related to minimizing the waste in cost and time, which affect the PDQ.

\subsection{Significance of the Study}

DB and DBB are central factors that affect PDQ including cost and time. Moreover, Lean Construction concepts are world widely used to minimize the waste and improve the quality, which made it a wise choice in the current case.

The significance of this study is the need for having more clear and specific answers regarding the reflection of using DB and DBB on PDQ, although many studies had mentions to both of them individually listing cons and bros. meanwhile, only few studies went for comparisons among both with no specific or clear answers to the question: which to use?

\subsection{Scope of Study}

This paper deals with construction projects from the perspective of delivery methods, with special mention to PDQ. It also chose the Lean Construction concepts as an option to apply among projects for minimizing the estimated cost and time. 


\section{LITERATURE REVIEW}

In DB method, a single entity or consortium is contractually responsible for both the design and construction of a project instead of the traditional strict organizational and contractual separation of these functions [22]. One of the first researchers to study this topic and suggested the six most commonly accepted DB variants was Janssens (1991) [4] to be:

1. Develop and Construct

2. DB 1-stage

3. DB 2-stage

4. Negotiated DB

5. Design and Manage

6. Turnkey

Around the same time, Masterman (1992) [6] identified four principal DB variants:

1. Novated DB

2. Package Deal

3. Turnkey

4. Develop and Construct

Other identifications went to outline the method as a whole without detailing. The system has two major variants, the "pure DB" and "fragmented DB". The categorization of the variants is based on the differentiation that each mode brings in terms of spatial, temporal and sentient differentiation [23]. For the "pure DB", all necessary design and construction expertise is within one organization (the contractor's), which has the responsibility to take client brief, design and construct to cost, time and satisfaction of the clients [24].

\subsection{Going DB}

DB had achieved a success in different applications. It has been compared with other project delivery systems since design and construction groups are part of the same organization and typically cooperate to complete the project within the predefined cast, time and quality limitations [25]. Some other positive reflection accompanied DB is safety within the construction sites, especially if the contractor was selected carefully with a goal of selecting a one with a good safety record, which may lower the chance of having an accident on jobsite which may lead to bad publicity and other negative consequences [26]. It's vital to utilize quality performance measurement not only to assess the quality performance of a DB firm, but also to allow the firm to benchmark itself against its competitors [27].

With mention to the use, more significant moves towards DB are evident from statistics and examples from the UK, USA and Australia [28]. In Japan, 10\% of construction projects are acquired through DB and the method is also gaining popularity in Singapore [29]. In the last decade, DB has been used extensively in Hong Kong to help deal with the problems associated with the traditional procurement method [30]. Three forms of variants, namely pure DB, enhanced DB and novation DB are most widely used [31]. Also, DB has been popularly adopted in the western countries and its use is increasing in the east, and it has even been recommended as an effective project delivery method for the $21^{\text {st }}$. century, even research in DB studies can benefit both practitioners and academics [32].

It's important to provide social learning experience, especially very early; teaching within the pedagogy of DB, particularly when attempting community and/or civic engagement, requires considerable skill and fluency with aspects of interpersonal communication, cultural awareness and sensitivity, reflective learning, and collaborative teaching [33]. With a 
prosperous attitude towards the use of DB, research further enhances the contractor's competitiveness, and a body of knowledge in DB can also be developed for achieving best practices in construction [34]. From the contractor's perspective, they are more positive about DB, and will take the lead if consultants do not grasp the opportunities [35]. Assuming that integration holds the key to the implementation of innovative practice and of taking advantage of the potential of DB method, the industry should look for opportunities to bring together the various professional disciplines within a single educational framework. However, this would require the integration of disparate departments and faculties, and so would have to overcome a number of logistical and operational difficulties if it were to be effective [36]. In their study, Jiann Yeh Lim et al. concluded for example, that the measures recommended in the study to promote pre-casting in DB projects received positive responses from the respondents, with the exception of introducing legislation and regulations [37].

To this end, seeking better results, it has made the case for better abstraction of client requirements by the incorporation of concurrent engineering principles as the bedrock for facilitating concurrent project development within the DB process, because there are many of the shortcomings of the conventional DB method [38].

\subsection{DB Concerns}

The global use of DB over the last two decades, the management skills of applying the DB method to specific project types and situations are still inadequate [39]. Chritamara et al. (2001) classified the major risks of running DB projects in terms of technical, financial and environmental aspects [40]. Sometimes, construction projects encounter problems using this method among their different stages. In the pre-construction stage, for example, the client is highly demanded to state the project requirements clearly; otherwise, the opportunity for disputes and variations will be increased due to incomplete documentation [41]. Moreover, the tender document is rigidly prepared and there is little room for innovative ideas [42]. The problem may be complicated when the client's brief is ambiguous and no communication of the client's precise wishes is conveyed to the contractor [43].

Moving to the construction stage, the contractors are inexperienced in managing the design team and design process when compared with the designers [44]. In DB projects, the single point entity requires the design professionals to work closely with the contractor who becomes the employer of the design teams, and as a result, the design consultants may be involved in serious conflict of interest situations such as the change in design with an increase in cost [44]. Eventually, Edmond W.M. Lam et al. (2007), after applying mean ranking on 16 problem attributes was conducted through their study, summarized the top five problems in running DB projects are 'The schedule was tight', 'Frequent changes were introduced by various end-users', 'Stress was placed on the project from the client', 'Frequent changes were introduced by various clients' and 'There was conflict of interests between design team members and the contractor' [28].

Furthermore, Edmond W.M. Lam et al. (2003), had a concentrated research in an article entitled "Potential Problems of Running Design-build Projects in Construction", but at the end, they concluded that having identified the preliminary problems, more proactive efforts should be made to study how to run DB projects successfully, indicating that applying this method may have successful feedbacks, but after following some considerations [45].

\subsection{Going DBB and Concerns}

The primary difference between DBB and DB for an owner is that DB places responsibility for infrastructure delivery into the hands of one party, which means the way construction was done when the building arts were simpler and a "master builder" managed the process [2]. The last 
authors also claimed that the first of two driving forces in the move to DBB was the perceived need for specialization in the design and construction industry. The second major force drove the use of DBB was the graft and corruption that flourished during the Civil War and never seemed too far away all the way up to present time; cheating in project construction was perceived to be easy when one party, the "master builder," controlled the entire process, whereas splitting the process and making one party the "watchdog" over the other party seemed to be the right answer [2].

On the other hand, the last authors said that the greatest shortcoming of DBB for the owner was the incredible liability placed on owners for accuracy of design; accuracy of design is the owner's responsibility, not the engineer's or architect's. Many other shortcomings were listed in details in the previous reference.

\subsection{DB vs. DBB}

Comparison studies were delivered among DB and DBB. USA study found that DB projects could produce equal and sometimes better quality performance than DBB [46]. At the macro level, it is found that DB projects performed significantly better than DBB projects in one area: delivery speed, whereas at the micro level of analysis, it is found that DB projects for residential homes and offices perform significantly better in a few areas compared to DBB projects [47]. They also concluded that the contract administrator is more comfortable with should be used, without worrying that their project performance will be significantly affected. One of the last authors in another article also mentioned that one of consultants' most important roles is to select the 'right' contractor for the project based on the contractor-related key determinants [48].

\section{HYPOTHESIS}

The paper assumes that grouping Design and Construction stages in one entity would enhance controlling their duties. No doubt that empowering control will escalate the PDQ.

Although this hypothesis goes for the DB option someway, but nothing is confirmed till reaching the results.

\section{RESEARCH APPROACH}

To test the paper hypothesis, a group of (6) features was assessed for measuring the variances between DB and DBB. The following question structure was circulated among the population to collect their feedbacks through interactive dialogues:

"Score against the following features for both of DB \& DBB using (1-5) scale. The scoring is based on thorough investigations for each method, and therefore, each feature scores should be supported by adequate information through a clear argument. After filling the form, there should be arguments against each feature.

1. Ease of repeating the project (more)

2. Outcomes produce the expected results (more)

3. Labour cost impact on the contract (less)

4. Final cost variation from original estimates (less)

5. Use of integrated design (more)

6. Strict engineer's supervision (more)

Scoring scale : 1 is the lowest and 5 is the highest"

The last questions were organized and tabulated for the purpose of collecting back the average scores (Appendix A). 
Enhancing the Project Delivery Quality; Lean Construction Concepts of Design-Build \& Design-BidBuild Methods

\subsection{Data Collection}

Through unstructured conversations with design and construction players: owners, consultants (design/supervision), and contractors, the data were collected by filling the given forms (Appendix A). They were asked to give their feedbacks regarding the (6) chosen features among DB \& DBB. They were requested to justify their scoring adding more details.

\section{RESULTS AND DISCUSSION}

The results obtained from the feedbacks of the interviewees were as follows:

Feedbacks were collected, tabulated, and classified to give the required statistics for the results' analyses. Table 1 below, shows the feedbacks for the DB method, which overall scored it 22.65 / 25.00 among the "six" features' evaluations.

Table 1. Feedbacks collected for DB Method

\begin{tabular}{|c|c|c|c|c|c|c|c|c|c|c|c|c|c|c|c|c|}
\hline $\mathrm{S}$ & $\begin{array}{l}\text { Features } \backslash \\
\text { Feedbacks }\end{array}$ & 1 & 2 & 3 & 4 & 5 & 6 & 7 & 8 & 9 & $\begin{array}{l}1 \\
0 \\
\end{array}$ & $\begin{array}{l}1 \\
1 \\
\end{array}$ & $\begin{array}{l}1 \\
2\end{array}$ & $\begin{array}{l}1 \\
3 \\
\end{array}$ & Average & $\begin{array}{l}\text { Ro } \\
\text { und }\end{array}$ \\
\hline 1 & $\begin{array}{l}\text { Ease of repeating } \\
\text { the project (more) }\end{array}$ & 5 & 4 & 4 & 4 & 4 & 4 & 5 & 5 & 5 & 4 & 4 & 5 & 5 & 4.461538 & 4.46 \\
\hline 2 & $\begin{array}{c}\text { Outcomes } \\
\text { produce the } \\
\text { expected results } \\
\text { (more) }\end{array}$ & 4 & 4 & 4 & 4.5 & 4 & 2 & 4 & 4 & 4 & 4.5 & 4.5 & 4 & 4 & 3.961538 & 3.96 \\
\hline 3 & $\begin{array}{c}\text { Labor cost impact } \\
\text { on the contract } \\
\text { (less) }\end{array}$ & 2 & 2 & 2 & 3 & 2 & 3 & 4 & 5 & 4 & 2 & 4 & 4 & 1 & 2.923077 & 2.92 \\
\hline 4 & $\begin{array}{c}\text { Final cost } \\
\text { variation from } \\
\text { original estimates } \\
\text { (less) }\end{array}$ & 4 & 4 & 4 & 1 & 4 & 2 & 1 & 5 & 5 & 2 & 4 & 4 & 5 & 3.461538 & 3.46 \\
\hline 5 & $\begin{array}{l}\text { Use of integrated } \\
\text { design (more) }\end{array}$ & 5 & 3 & 4 & 4 & 4 & 3 & 4 & 4 & 5 & 4 & 5 & 4 & 5 & 4.153846 & 4.15 \\
\hline 6 & $\begin{array}{c}\text { Strict engineer's } \\
\text { supervision } \\
\text { (more) }\end{array}$ & 4 & 3 & 5 & 3 & 4 & 2 & 4 & 5 & 4 & 3 & 3 & 5 & 3 & 3.692308 & 3.69 \\
\hline & Total Scores & 24 & 20 & 23 & $\begin{array}{c}19 . \\
5\end{array}$ & 22 & 16 & 22 & 28 & 27 & $\begin{array}{c}19 . \\
5\end{array}$ & $\begin{array}{c}24 . \\
5\end{array}$ & 26 & 23 & 22.65384615 & $\begin{array}{c}22.6 \\
5\end{array}$ \\
\hline
\end{tabular}

Similarly, table 2 below, shows the feedbacks for the DBB method, which overall scored it $17.15 / 25.00$ among the "six" features' evaluations.

Table 2. Feedbacks collected for DBB Method

\begin{tabular}{|c|c|c|c|c|c|c|c|c|c|c|c|c|c|c|c|c|}
\hline $\mathrm{S}$ & $\begin{array}{c}\text { Features } \backslash \\
.\end{array}$ & 1 & 2 & 3 & 4 & 5 & 6 & 7 & 8 & 9 & $\begin{array}{c}1 \\
0\end{array}$ & $\begin{array}{c}1 \\
1\end{array}$ & $\begin{array}{c}1 \\
2\end{array}$ & $\begin{array}{c}1 \\
3\end{array}$ & Average & $\begin{array}{c}\text { Ro } \\
\text { und }\end{array}$ \\
\hline 1 & $\begin{array}{c}\text { Ease of repeating } \\
\text { the project (more) }\end{array}$ & 3 & 2 & 1 & $\begin{array}{c}2 . \\
5\end{array}$ & 2 & 4 & 3 & 2 & 2 & $\begin{array}{c}2 . \\
5\end{array}$ & 3 & 2 & 2 & $\begin{array}{c}2.384615 \\
385\end{array}$ & $\begin{array}{c}2.3 \\
8\end{array}$ \\
\hline $\begin{array}{c}\text { Outcomes } \\
\text { produce the } \\
\text { expected results } \\
\text { (more) }\end{array}$ & 3 & 2 & 3 & 3 & 2 & 5 & 1 & 2 & 3 & $\begin{array}{c}3 . \\
5\end{array}$ & 3 & 2 & 4 & $\begin{array}{c}2.807692 \\
308\end{array}$ & $\begin{array}{c}2.8 \\
1\end{array}$ \\
3 & $\begin{array}{c}\text { Labor cost impact } \\
\text { on the contract } \\
\text { (less) }\end{array}$ & 5 & 3 & 4 & 2 & 4 & 4 & 2 & 2 & 3 & 3 & 3 & 2 & 5 & $\begin{array}{c}3.230769 \\
231\end{array}$ & 2.2 \\
\hline
\end{tabular}




\begin{tabular}{|c|c|c|c|c|c|c|c|c|c|c|c|c|c|c|c|c|}
\hline 4 & $\begin{array}{c}\text { Final cost } \\
\text { variation from } \\
\text { original estimates } \\
\text { (less) }\end{array}$ & 1 & 2 & 2 & $\begin{array}{l}4 . \\
5\end{array}$ & 1 & 5 & 4 & 2 & 2 & $\begin{array}{c}4 . \\
5\end{array}$ & $\begin{array}{c}4 . \\
5\end{array}$ & 3 & 1 & $\begin{array}{c}2.807692 \\
308\end{array}$ & $\begin{array}{c}2.8 \\
1\end{array}$ \\
\hline 5 & $\begin{array}{c}\text { Use of integrated } \\
\text { design (more) }\end{array}$ & 1 & 2 & 2 & 2 & 3 & 5 & 3 & 3 & 2 & 3 & $\begin{array}{l}3 . \\
5\end{array}$ & 1 & 1 & $\begin{array}{c}2.423076 \\
923 \\
\end{array}$ & $\begin{array}{c}2.4 \\
2 \\
\end{array}$ \\
\hline 6 & $\begin{array}{l}\text { Strict engineer's } \\
\text { supervision } \\
\text { (more) }\end{array}$ & 5 & 3 & 2 & 4 & 3 & 5 & 3 & 2 & 3 & 4 & $\begin{array}{l}4 . \\
5\end{array}$ & 3 & 4 & 3.5 & 3.5 \\
\hline & Total Scores & $\begin{array}{l}1 \\
8\end{array}$ & $\begin{array}{l}1 \\
4\end{array}$ & $\begin{array}{l}1 \\
4\end{array}$ & $\begin{array}{l}1 \\
8\end{array}$ & $\begin{array}{l}1 \\
5\end{array}$ & $\begin{array}{l}2 \\
8\end{array}$ & $\begin{array}{l}1 \\
6\end{array}$ & $\begin{array}{l}1 \\
3\end{array}$ & $\begin{array}{l}1 \\
5\end{array}$ & $\begin{array}{c}2 \\
0 . \\
5\end{array}$ & $\begin{array}{l}2 \\
1 . \\
5\end{array}$ & $\begin{array}{l}1 \\
3\end{array}$ & $\begin{array}{l}1 \\
7\end{array}$ & $\begin{array}{c}17.15384 \\
615\end{array}$ & $\begin{array}{l}17 . \\
15\end{array}$ \\
\hline
\end{tabular}

\subsection{Ease of Repeating the Project (more: $\mathrm{DB}=4.46, \mathrm{DBB}=\mathbf{2 . 3 8}$ ), Fig. 1}

It's direct to say that an individual could easily repeat an activity or a group of activities once he/she owns the know-how, which is escalated by the cumulative experience. The same point could be applied to the singular entity rather than different entities that are represented here by DB and DBB respectively. In detail, DB has the chance to collect and document all practices occurred in a project, which facilitates the repetition of similar projects in future. On the other hand, DBB has not the same privilege regarding the documentation that could facilitate the project repetition the same way; this was interpreted obviously in the scoring of this feature.
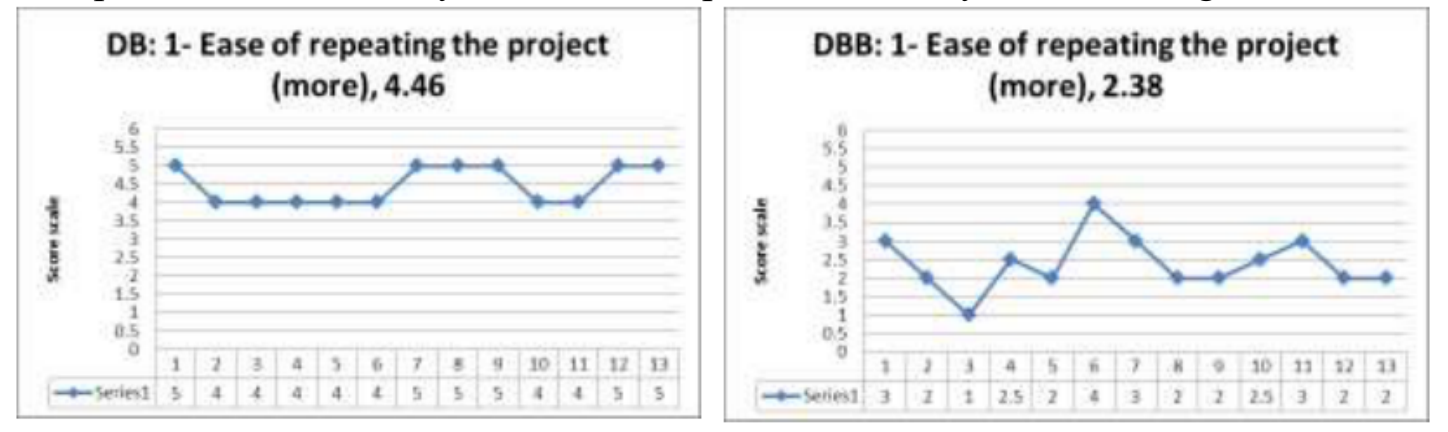

Figure 1 Ease of repeating the project of DB vs. DBB Charts

\subsection{Outcomes Produce the Expected Results (more: $D B=3.96, D B B=2.81$ ), Fig. 2}

The project outcomes are ideally considered as the reflection of its expected results, which are also set by its management, especially which is affiliated to the design team. As a result, it's closer for a team to get the project outcomes almost as they expected for the results, rather than applying that through different teams. It's the case here for following the DB or DBB methods, because DB collects all project activities under one ceiling performing as one team. The collected feedbacks in this feature confirm the same concept that is DB got a higher score than DBB, which was a logical result. The whole interviewees went almost for the same trend, except for (2). After collecting the feedbacks, there were some contacts with the interviewees who gave different feedbacks; they reported that their scoring in this features reflected a misunderstanding of the question. However, the study decided to leave the feedbacks as they are, since the average still confirms the trend. 

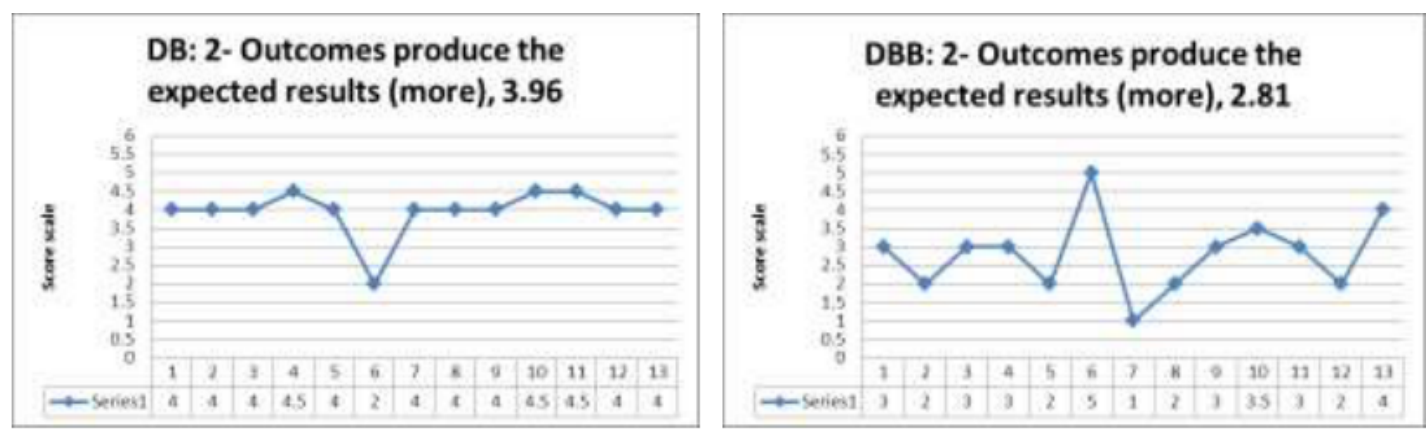

Figure 2. Outcomes produce the expected results of DB vs. DBB Charts

\subsection{Labor Cost Impact on the Contract (less: $D B=2.92$, $D B B=2.23$ ), Fig. 3}

The difference among the (2) methods regarding this feature is not clear enough, may be because the labor cost impact on different methods is almost near. However, managing the manpower (labor) is most likely better in DB as they're controlled by a centralized management. On the other hand, in DBB there is decentralization in labor management,

Which will have more impact on the contract regarding this point. Again, as the difference between $\mathrm{DB}$ and $\mathrm{DBB}$ is not clear here, the scoring was struggling somehow among interviewees, but at the end, there was an average slight difference counts to DB over DBB.
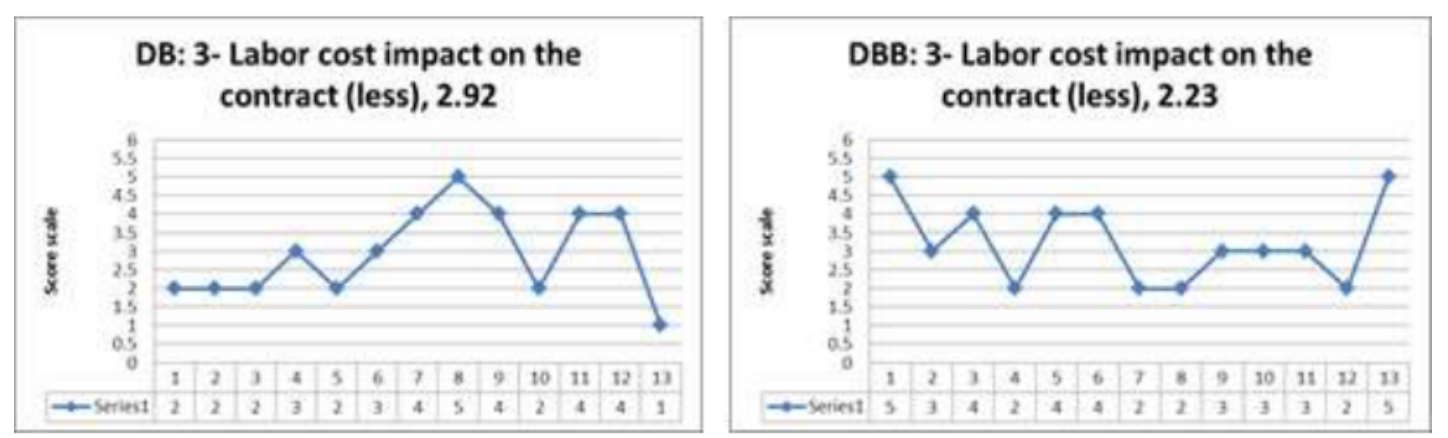

Figure 3. Labor cost impact on the contract of DB vs. DBB Charts

\subsection{Final Cost Variation from Original Estimates (less: $\mathrm{DB}=3.46, \mathrm{DBB}=2.81$ ),} Fig. 4

Although the DBB method permits an accurate systems to set the cost estimates of the project through different types of contracting alternatives, but still having the complete cost estimate process in-house in DB leads to more control among the variation from the original estimates. It could be monitored from different perspectives while either compare between the two estimates (original and final), or from the part of change orders' costs; in both cases, DB results in less final cost variation from the original one, and the average score of this feature reflects this fact. 

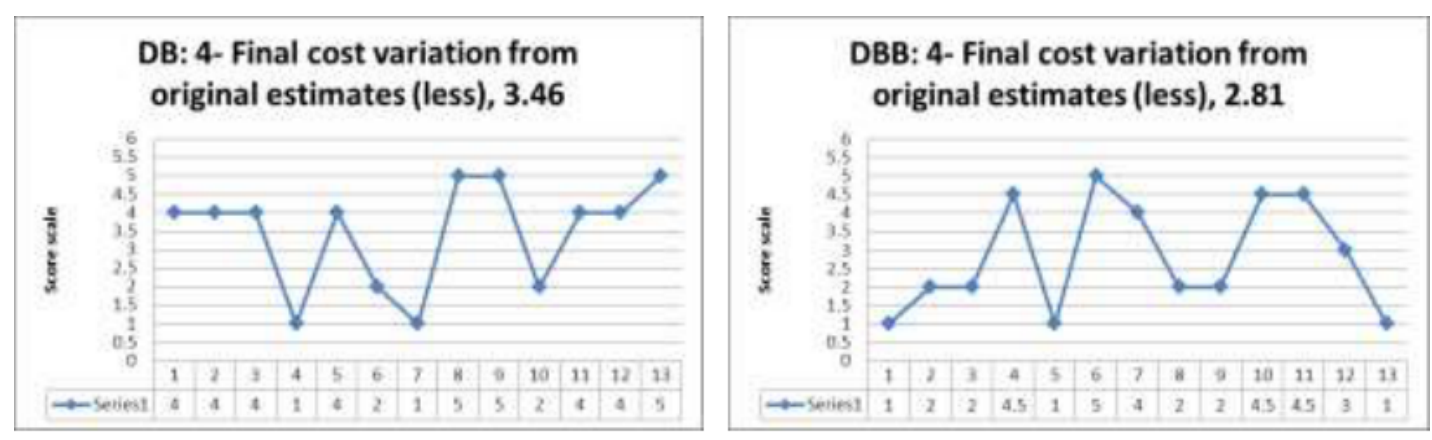

Figure 4. Final cost variation from original estimates of DB vs. DBB Charts

\subsection{Use of Integrated Design (more: $\mathrm{DB}=4.15, \mathrm{DBB}=2.42$ ), Fig. 5}

The use of integrated design refers to the collaborative work among the design team with its whole disciplines. The comprehensive definition also involves, in some cases, the construction or even project manager in earlier stages of design in order to guarantee a better link and solutions among the two main project stages: design and construction. The triangle: owner, engineer, and contractor may be utilizing the same kind of integrated design, which contributes, vastly, in excluding any unwanted issues such as week feedbacks to the owner, in the construction stage. Of course, this kind of design could be used in both methods, but it's still easier someway, when used in DB than DBB, that is the presence of either the construction or project managers within the same company, side by side with the design team facilitates the work. The scoring in this feature went clearly to DB as a reflection of the discussion above.
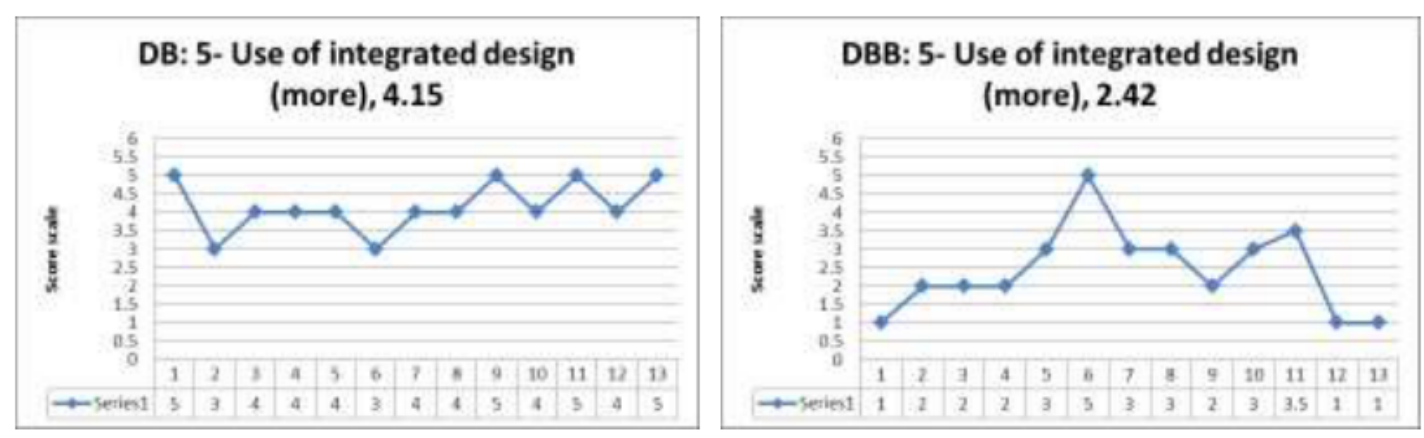

Figure 5. Use of integrated design of DB vs. DBB Charts

\subsection{Strict Engineer's Supervision (more: $\mathrm{DB}=3.69, \mathrm{DBB}=3.50$ ), Fig. 6}

In the engineering supervision, DBB is supposed to have the upper hand in this feature, as the supervision team is working, according to contractual issues, against the construction team lead by the contractor. Whereas in the DB, both teams are affiliated to the same company and not supposed to hunt mistakes of others, especially the supervision team to the construction one. This is true, but let's monitor this process from other perspective: constructive and destructive. By experience, the notes of supervision conducted thru supervisors are exaggerated for different reasons, but briefly, this usually happens when we have two contracts in the construction stage: supervision and contractor, which generates, sometimes, destructive notes. In the same way, if the two teams were working for the same entity, the supervision notes would fix the construction defects only and not going further: the main target of both teams are the same, 
which is finishing the project safely with less conflicts and problems, so the notes here are constructive and support the project.
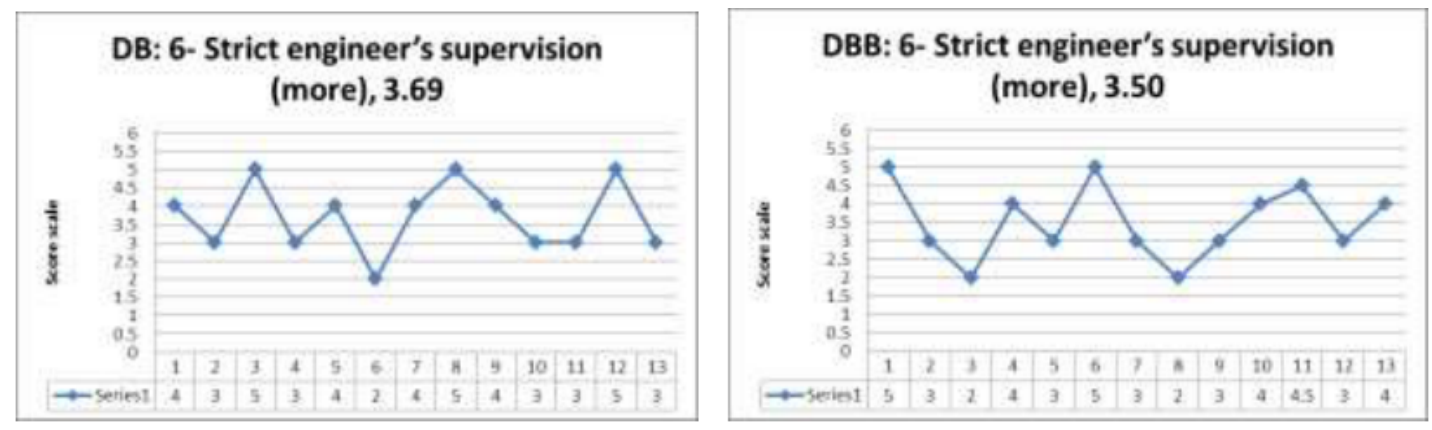

Figure 6. Strict engineer's supervision of DB vs. DBB Charts

Eventually, it was clear through the appraisal that both DB and DBB have positive points in some features, and this is reflected in the close scoring results as presented. However, DB (3.77) in our case here got a slightly higher score over DBB (2.69), which indicates to the promising results of this method, even sometimes or in general. The average score of DB rises a little bit above DBB; please refer to Fig. 7 below.
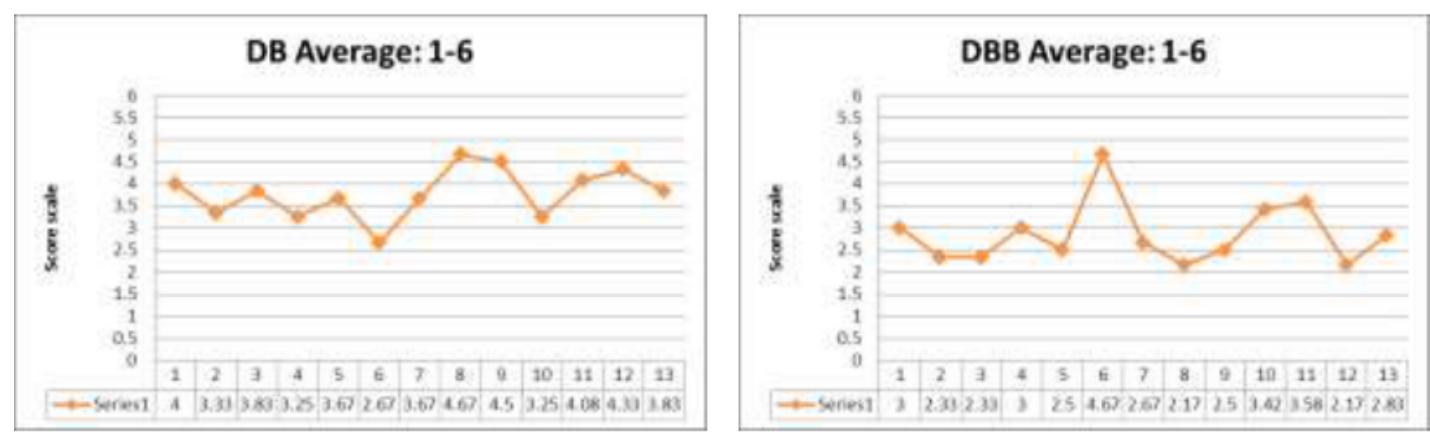

Figure 7. Average Scores of DB (3.77) vs. DBB (2.69) Charts

\section{CONCLUSION}

Since the scoring matrix is an evaluation tool used thru human, it's subject to the effect of their culture or background, so the final results are not a rigorous indicator, especially when the variances are limited. However, even they have near scores, the study had a perspective: DB as a delivery method should count while deciding among alternatives; it worth. Although it is less used, compared with DBB according to the records, but there was an increasingly dependence on DB monitored in the last years and the ratio is still increasing. This trend is confirmed earlier by previous researches and also through this paper. DB delivery method owns sound strategies and managing systems that made it eligible to be dependable and more used with extensive degree of trust and confidence. In conclusion, if DB is not clearly better than DBB in the show results, it is still a potential challenger of it, as well as others not mentioned here, and DB worth feasibility, for use as a probable delivery method in construction projects.

\section{REFERENCES}

[1] Mark Hall \& Cyril Tomkins, A cost of quality analysis of a building project: towards a complete methodology for design and build, Construction Management and Economics, 19:7, 727-740, DOI: 10.1080/01446190110066146, 2001 
[2] P. Thomas Gard PE and Esq. and PMP, Fast and Innovative Delivery of High Performance Building: Design-build Delivers with Less Owner Liability, Strategic Planning for Energy and the Environment, 23:4, 7-22, DOI: 10.1080/10485230409509647, 2004

[3] Bo Xia, Albert P.C. Chan \& Martin Skitomre, A Classification Framework for DesignBuild Variants from an Operational Perspective, International Journal of Construction, 2012

[4] Janssens D.E.L, Design-Build Explained, Macmillan Education Ltd, London, 1991

[5] Akintoye A, "Design and build: a survey of construction contractors' views." Construction Management and Economics, 12 (1), 1994, pp 155-163.

[6] Masterman, J.W.E, An introduction to Building Procurement Systems $1^{\text {st }}$ Edition, E\&FN Spon, London, 1992

[7] Quatman G.W, Design-Build for the Design Professional, Aspen Law \& Business, Geithersburg, 2001

[8] Gransberg D.D., Koch J.E., and Molenaar K.R, Preparing for design-build projects. ASCE Press, USA, 2006

[9] Beard, J.L., Loulakis SR. M. C., and Wundram E.C, Design-Build-Planning through Development, McGraw-Hill, NY, 2006

[10] El Wardani, M.A., Messner, J.I. and Horman, M.J, "Comparing procurement methods for design-build projects." Journal of Construction Engineering and Management, 132(3), 2006, pp 230-238.

[11] Katar I. M. \& Howeidy D. R, Effective Construction Utilizing Design-Build Vs. DesignBid-Build Methods; 5-Feature Appraisal (Time-Drawings-Calendar-CommunicationChanges), International Journal of Civil Engineering and Technology (IJCIET) 9(13), 2018, pp. 918-931.

[12] Abdulaziz Banawi \& Melissa M. Bilec, A framework to improve construction processes: Integrating Lean, Green and Six Sigma, International Journal of Construction Management, 14:1, 2014, 45-55, DOI: 10.1080/15623599.2013.875266.

[13] Daniel Sage, Andrew Dainty \& Naomi Brookes, A 'Strategy-as-Practice' exploration of lean construction strategizing, Building Research \& Information, 40:2, 2012, pp 221-230, DOI: 10.1080/09613218.2012.655925.

[14] [14] Samuel Yen-Liang Yin, H. Ping Tserng, Shih Ning Toong \& Thanh Long Ngo, An improved approach to the subcontracting procurement process in a lean construction setting, Journal of Civil Engineering and Management, 20:3, 2014, pp 389-403, DOI: 10.3846/13923730.2013.801900.

[15] Nimesha Vilasini, Thomas R. Neitzert \& James O. Rotimi, Correlation between Construction Procurement Methods and Lean Principles, International Journal of Construction Management, 11:4, 2011, pp 65-78, DOI: 10.1080/15623599.2011.10773179.

[16] Heng Li, H L Guo, Yan Li \& Martin Skitmore, From IKEA Model to the Lean Construction Concept: A Solution to Implementation, International Journal of Construction Management, 12:4, 2012, pp 47-63, DOI: 10.1080/15623599.2012.10773200.

[17] Lianying Zhang, Xi Chen \& Yongqing Suo, Interrelationships among critical factors of work flow reliability in lean construction, Journal of Civil Engineering and Management, 23:5, 2017, pp 621-632, DOI: 10.3846/13923730.2016.1217921.

[18] Stuart D. Green \& Susan C. May, Lean construction: arenas of enactment, models of diffusion and the meaning of 'leanness', Building Research \& Information, 33:6, 2005, pp 498-511, DOI: 10.1080/09613210500285106.

[19] Huseyin Erol, Irem Dikmen \& M. Talat Birgonul, Measuring the impact of lean construction practices on project duration and variability: A simulation-based study on residential buildings, Journal of Civil Engineering and Management, 23:2, 2017, pp 241-251, DOI: 10.3846/13923730.2015.1068846. 
[20] Daria Zimina, Glenn Ballard \& Christine Pasquire, Target value design: using collaboration and a lean approach to reduce construction cost, Construction Management and Economics, 30:5, 2012, pp 383-398, DOI: 10.1080/01446193.2012.676658.

[21] S. D. GREEN, The missing arguments of lean construction, Construction Management \& Economics, 17:2, 1999, pp 133-137, DOI: 10.1080/014461999371637.

[22] Songer A.D., and Molenaar K.R, "Project Characteristic for Successful Public-Sector Design-Build." Journal of Construction Engineering and Management, ASCE, 123(1), 1997, pp 34-40.

[23] Rowlinson, S. M, Comparison and Contracting Systems for Industrial Building, in Managing Construction Worldwide: The Organization and Management of Construction CIB W-55. Ed. by P. R. Lansley, P. R. and P. A. Harlow. UK: London, 1987, pp 55-65.

[24] Stephen Okunlola Ojo , Omotayo Aina \& Aderemi Yakeen Adeyemi, A comparative analysis of the performance of traditional contracting and design-build procurements on client objectives in Nigeria, Journal of Civil Engineering and Management, 17:2, 2011, pp 227-233.

[25] Alaattin Kanoglu, An Integrated System for Design/Build Firms to Solve Cost Estimation Problems in the Design Phase, Architectural Science Review, 46:1, 2003, pp 37-47, DOI: 10.1080/00038628.2003.9696962.

[26] Carla Lopez Del Puerto PH.D., Kelly Strong PH.D. \& Megan Miller MS, Analysis of Owners Safety Management Approaches in Design-Build Projects, International Journal of Construction Education and Research, 9:4, 20103, pp 307-316, DOI: 10.1080/15578771.2012.756436.

[27] David Arditi \& Dong-Eun Lee, Assessing the corporate service quality performance of design-build contractors using quality function deployment, Construction Management \& Economics, 21:2, 2003, pp 175-185, DOI: 10.1080/0144619032000079716.

[28] Palaneeswaran, E., and Kumaraswamy, M. M, "Reinforcing Design-Build Contractor Selection: A Hong Kong Perspective", the Hong Kong Institution of Engineers Transactions, 8(1), 2001, pp 7-12.

[29] [29] Chan, A. P. C., Ho, D. C. K., and Tam, C. M, "Evaluation Criteria of Public-Sector Design and Build Projects in Hong Kong", Journal of Construction Research, 2(2), 2001, pp 135-145.

[30] Chan, A. P. C, "Evaluation of Enhanced Design and Build System - A Case Study of a Hospital Project", Construction Management and Economics, 18, 2000, pp 863-871.

[31] Edmond W.M. Lam, Albert P.C. Chan \& Daniel W.M. Chan, An Empirical Study on the Problems of Running Design and Build Projects in Construction, International Journal of Construction Management, 7:1, 2007, pp 1-15, DOI: 10.1080/15623599.2007.1077309.

[32] Edmond W. M. Lam, Albert P. C. Chan \& Daniel W. M. Chan, Barriers to Applying the Design-build Procurement Method in Hong Kong, Architectural Science Review, 49:2, 2006, pp 189-195, DOI: 10.3763/asre.2006.4926.

[33] Chad Schwartz, Laura Morthland \& Shannon Mcdonald, Building a Social Framework: Utilising Design/Build to Provide Social Learning Experiences for Architecture Students, Architectural Theory Review, 19:1, 2014, pp 76-91, DOI: 10.1080/13264826.2014.894606.

[34] Edmond W. M. Lam, Albert P. C. Chan \& Daniel W. M. Chan, Development of the DesignBuild Procurement System in Hong Kong, Architectural Science Review, 47:4, 2004, pp 387-397, DOI: 10.1080/00038628.2000.9697548.

[35] Albert P. C. Chan, Evaluation of enhanced design and build system a case study of a hospital project, Construction Management and Economics, 18:7, 2000, pp 863-871, DOI: 10.1080/014461900433140.

[36] David R. Moore \& Andrew R. J. Dainty, Intra-team boundaries as inhibitors of performance improvement in UK design and build projects: a call for change, Construction Management \& Economics, 19:6, 2001, pp 559-562, DOI: 10.1080/01446190110055508. 
[37] Jiann Yeh Lim, Shou Qing Wang \& R. Tiong, Precasting in Singapore's Design \& Build Projects, International Journal of Construction Management, 2:1, 2002, pp 1-12, DOI: 10.1080/15623599.2002.10773026.

[38] Chimay J. Anumba \& Nosa F. O. Evbuomwan, Concurrent engineering in design-build projects, Construction Management \& Economics, 15:3, 1997, pp 271-281, DOI: 10.1080/014461997373006.

[39] Konchar, M. D., Sanvido, V. E., and Moore, S. D, "The Benefits of Design-Build Contracting in the United States", Proceedings of the International Conference on Construction Process Reengineering, Australia, 14-15 July 1997, pp191-201.

[40] Chritamara, S., and Ogunlana, S. O, "Problems Experienced on D/B Projects in Thailand", Journal of Construction Procurement, 7(1), 2001, pp 73-93.

[41] Lam, K. C, "Management of Building Services Procurement for Highly Serviced Healthcare Facilities", Building Journal Hong kong China, Jun-00, 2000, pp 70-81.

[42] Tao, H, "Design \& Build: Challenge \& Response", Design/Build Symposium, The Architectural Services Department, Hong Kong, May, 1996

[43] Masterman, J. W. E, An introduction to building procurement systems, E\&FN Spon, 2002

[44] Smith, T. E, "D/B: The Architects' Perception in the HK Context", Design/Build Symposium, The Architectural Services Department, Hong Kong, May 1996,

[45] Edmond W.M. Lam, Albert P.C. Chan \& Daniel W.M. Chan, Perceptions on the Application of Design-Build Procurement System in Hong Kong, Architectural Science Review, 46:4, 2003, pp 419-425, DOI: 10.1080/00038628.2003.9697014.

[46] M. KONCHAR, AND V. SAMrLDO. Comparison of US project delivery systems. Journal of Construction Engineering and Management, Vol. 124, 1998, pp. 435 - 444.

[47] Florence Yean Yng Ling \& Shu Hui Kerh , Comparing the Performance of Design-Build and Design-Bid-Build Building Projects in Singapore, Architectural Science Review, 47:2, 2004, pp 163-175, DOI: 10.1080/00038628.2004.9697040.

[48] Florence Yean Yng Ling, Key determinants of performance of design-bid-build projects in Singapore, Building Research \& Information, 32:2, 2004, pp 128-139, DOI: 10.1080/096132103200048497.

\section{APPENDIX A}

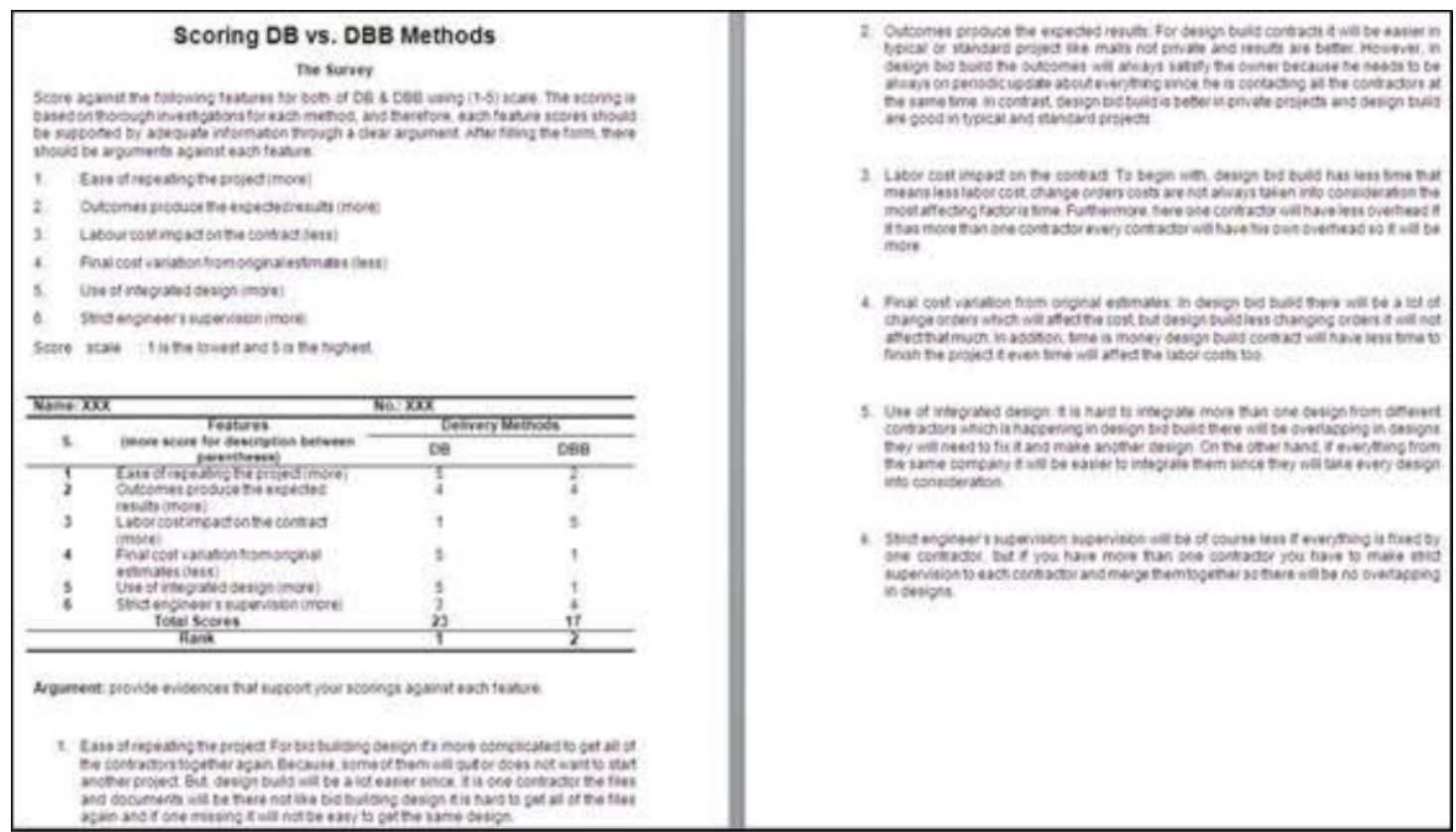

A Survey sample collected from the population feedbacks 